\title{
Małgorzata Ostrowska, Jacek J. Błeszyński, Czas wolny jako środowisko życia. Perspektywa pedagogiczna, Wydawnictwo Naukowe PWN, Warszawa 2016, ss. 160
}

Czas wolny jest kategorią pojęciową społecznie pożądaną. Czas wolny jako termin wszedł do nauki wraz z nastaniem społeczeństwa przemysłowego, w którym człowiek zaczął funkcjonować w dwóch środowiskach: pracy i prywatnym. Czas wolny jest różnorodnie definiowany w zależności od perspektywy, w której dokonuje się jego analizy. W kręgu kultury euroamerykańskiej, cechującej się stosunkowo wysoką liczbą osób pracujących i uczących się, czas wolny jawi się jako idea wypoczynku i możliwość odreagowania codziennego stresu (por. Arnold 1989). Czas wolny - etymologicznie - oznacza porę, w której człowiek wykonuje czynności, na które ma ochotę i których nie może wykonywać w innych porach ze względu na aktywność zawodową, uczenie się lub inne obowiązki, np. wynikające z roli społecznej członka rodziny (por. Rodziewicz 2014).

Czas wolny może być analizowany z różnej perspektywy: filozoficznej, antropologicznej, socjologicznej, psychologicznej i pedagogicznej. Aktualnie mieści się w zainteresowaniach różnych szczegółowych subdyscyplin, np. pedagogiki specjalnej czy ekonomii. Przy tak precyzyjnym podejściu do tej kategorii pojęciowej analizie podlegają również: wspomaganie powstawania czasu wolnego, jego zagospodarowanie czy wykorzystanie jako kategorii diagnostycznej. Filozofia interesuje się czasem wolnym od wieków. Wielu wybitnych myślicieli stawiało czas wolny w kręgu swoich filozoficznych dysput, np. Arystoteles nie uznawał czasu wolnego (schola) ani za czas wypoczynku, ani za koniec pracy. Filozofia zajmuje się również czasem wolnym od strony jego utraty i problemów z zagospodarowaniem, współcześnie szczególnie w przypadku dzieci i młodzieży (Przecławski 2005). W antropologii czas jest cechą danej kultury, jest wartością tożsamości kulturowej. Od tego jak, dane dziedzictwo kulturowe interpretuje czas, zależy egzystencja wspólnot. Założone w 1966 roku International Society for the Study of 
Time zajmuje się studiami nad czasem w ujęciu interdyscyplinarnym, organizując międzynarodowe konferencje i wydając własne publikacje poświęcone tej problematyce. Uznano zatem, że czas jest wart uwagi szczególnej, bo odgrywa w życiu człowieka rolę wielce znaczącą. Literatura antropologiczna poświęcona czasowi jest imponująca, ale nadal nieuporządkowana i ciągle w początkowym stadium rozwoju (Maxwell 1972, s. 47). Antropologiczne spojrzenie na życie codzienne ludzi w ujęciu historycznym pozwala na analizę czasu wolnego od starożytności, po jego digitalizację i interpretację w epoce rozwiniętego konsumpcjonizmu. Francuski socjolog Jeff Dumazedier twierdził, że „czas wolny obejmuje wszystkie zajęcia, którym jednostka może się oddawać z własnej chęci bądź dla odpoczynku, rozrywki, rozwoju swych wiadomości lub swego kształcenia, swego dobrowolnego udziału w życiu społecznym, po uwolnieniu się z obowiązków zawodowych, rodzinnych czy społecznych" (Czajka 1979, s. 39). Socjologia zatem interpretuje tę kategorię pojęciową w wielu płaszczyznach: wypoczynku, rozwoju społecznego, rekreacji, życia towarzyskiego czy samorozwoju. W psychologii zainteresowanie czasem wolnym narodziło się stosunkowo późno, co wynikało z przekonania, że czynności wykonywane przez człowieka w każdym czasie jego aktywności są tożsame. Okazało się jednak, że jest to przekonanie mylne i psychologiczna analiza czasu wolnego jednostki rozwija się jako odrębny dział w psychologii (Migdał 2011). Jednym z dowodów tej tezy jest brak $\mathrm{w}$ psychologii ujęcia problematyki czasu wolnego w pespektywie czasowej w realizacji zadań (Nuttin 1985; Zalewski 1994) czy orientacji w czasie psychologicznym (Eukaszewski 1983; Zimbardo 1990).

Z perspektywy pedagogicznej czas wolny stanowi kategorię, przez którą można realizować cele wychowania. Stanowi poważną część literatury przedmiotu w pedagogice społecznej i pedagogice specjalnej. Ta ostatnia subdyscyplina traktuje czas wolny jako narzędzie/środek w procesie rehabilitacji, rozumianej jako system oddziaływań o charakterze medycznym, psychologicznym, pedagogicznym, zawodowym i społecznym wobec jednostki z odchyleniami od normy, np. rozwojowej czy społecznej. Przedmiotowej kategorii została poświęcona publikacja Czas wolny jako środowisko życia. Perspektywa pedagogiczna (2016) autorstwa Małgorzaty Ostrowskiej i Jacka J. Błeszyńskiego. Jest to pozycja z pogranicza nauk: pedagogiki społecznej, pracy socjalnej, oligofrenopedagogiki i resocjalizacji. Kategorią analityczną jest środowisko człowieka, a czas wolny posłużył autorom jako narzędzie do diagnozy i realizacji celów wychowawczych. Zadanie, jakie postawili sobie twórcy, jest trudne do wykonania w jednej pozycji książkowej, na 160 stronach. Przedstawienie zróżnicowania definicyjnego i perspektyw, służących 
interpretacji kategorii pojęciowej i diagnostycznej, jaką jest czas wolny, to poważne wyzwanie naukowe i wydawnicze. Publikację o charakterze teoretyczno-badawczym podzielono na dwie części. W pierwszej, zatytułowanej „Różne oblicza czasu wolnego”, Orłowska porządkuje wiedzę o czasie wolnym w ujęciu definicyjnym i z pozycji funkcji tego terminu. Wprowadza pojęcie czasu na wpół wolnego, wyjaśniając je czytelnikowi. Dotyka koncepcji kapitałów Pierre’a Bourdieu, choć myśli tej nie rozbudowuje. Ta część książki jest rzetelnie opracowana i wyraźnie widać, że autorka dobrze się czuje w tej problematyce. Jest to najmocniejszy merytorycznie moduł książki, składający się z trzech rozdziałów. Druga część publikacji - „Społeczny wymiar czasu wolnego we współczesnej Polsce" - jest poświęcona obywatelskiej randze czasu wolnego w dzisiejszej Polsce, co ilustrują zaprezentowane badania, również autorskie. Ten fragment zdecydowanie faworyzuje czas wolny dziecka, z jednym rozdziałem poświęconym w całości dziecku/młodzieży z niepełnosprawnością intelektualną $\mathrm{w}$ stopniu lekkim - ich aktywności oraz postrzeganiu czasu wolnego. Autorzy traktują czas wolny jako kategorię diagnostyczną oraz przejaw/narzędzie zmian społecznych i dlatego szkoda, że nie opracowali rekomendacji dla praktyki pedagogiki społecznej, pracy socjalnej i pedagogiki specjalnej. Kilka wskazówek dotyczących posługiwania się czasem wolnym jako kategorią diagnostyczną, narzędziem zmiany lub środkiem $\mathrm{w}$ procesie rehabilitacji wzbogaciłoby pozycję i nadałoby jej wymiar społecznie wartościowy. Pozycja ma bogatą bibliografię, co świadczy o profesjonalnym podejściu do problemu. Powstaje jednak wątpliwość - kto jest adresatem tej książki? Czytelnik sugeruje się tytułem, który w tym wypadku kieruje pozycję do pedagogów, mających zamiar posłużyć się czasem wolnym jako przestrzenią do realizacji określonych celów wychowawczych. I tu może wystąpić kolizja między tymi oczekiwaniami a treścią.

Ciekawym wątkiem mogłoby być również potraktowanie czasu wolnego jako przestrzeni, gdzie współczesny człowiek może występować w rolach społecznych odmiennych od swojej codzienności. Warto byłoby zastąpić fragment pozycji poświęcony zagadnieniom związanym $\mathrm{z}$ resocjalizacją rozdział 7. „Czas wolny - źródło nadziei” - właśnie odmianą w pełnieniu powinności wspólnotowych. Pojęcie roli społecznej, w swej klasycznej postaci, jest definiowane jako dynamiczny aspekt statusu jednostki określany przez wzorce kulturowe. Jednostka stosuje się do standardów behawioralnych przypisywanych indywidualnym statusom przez społeczeństwo. Tymi normami są: postawy, wartości i zachowania (Manterys 2008, s. 101). Spędzając czas wolny, jednostka może świadomie lub nieświadomie odchodzić od narzuconych kulturowo kanonów własnego statusu. Jest to jeden z wa- 
riantów zmiany, jaką niesie czas wolny. W tym wypadku zmiany społecznej w wymiarze indywidualnym.

Uważam, że warto zapoznać się z publikacją, aby zdać sobie sprawę ze znaczenia czasu wolnego w egzystencji współczesnego człowieka. Książka uświadamia prawo człowieka do posiadania, zagospodarowywania i wykorzystywania czasu wolnego w indywidualnej części przestrzeni społecznej. Ukazuje również rolę czasu wolnego w życiu dziecka/młodzieży i wagę tego pojęcia jako kategorii diagnostycznej w pedagogice.

Ditta Baczała

\section{Bibliografia}

Arnold P. (1989), On the relationships between education, work and leisure: Past, present and future, "British Journal of Educational Studies", vol. 37, no. 2.

Czajka S. (1979), Z problemów czasu wolnego, Instytut Wydawniczy, Warszawa.

Łukaszewski W. (1983), Orientacja temporalna jako jeden z aspektów osobowości, [w:] W. Łukaszewski (red.), Osobowość - orientacja temporalna - ustosunkowanie do zmian, Wydawnictwo Uniwersytetu Wrocławskiego, Wrocław.

Maxwell R.J., Anthropological Perspectives, [w:] H. Yaker, H. Osmond, P. Cheek (eds.), The Future of Time. Man,s Temporal Environment, New York.

Manterys A. (2008), Sytuacje społeczne, Zakład Wydawniczy NOMOS, Kraków.

Migdał K. (2011), Psychologia czasu wolnego, ALMAMER, Warszawa.

Nuttin J. (1985), Future time perspective and motivation, Leuven University Press and Erlbaum, Leuven.

Przecławski K. (2005), Życie to podróż, Wydawnictwo Akademickie ŻAK, Warszawa.

Rodziewicz A. (2014), O czasie wolnym i logice pokoju, „Przegląd Filozoficzno-Literacki" $3-4$, s. 289-318.

Zimbardo P. (1990), The Stanford Time Perspective Inventory, Stanford University Press, Stanford.

Zaleski Z. (red.), (1994), Psychology of future orientation, Towarzystwo Naukowego Katolickiego Uniwersytetu Lubelskiego, Lublin. 